\title{
O DIREITO MINERÁRIO À LUZ DOS REGIMES DE APROVEITAMENTO DOS RECURSOS MINERAIS NO BRASIL
}

\author{
Sérgio Alexandre de Moraes Braga Junior \\ Universidade Federal do Rio Grande do Norte (UFRN), Rio \\ Grande do Norte. \\ s.alexandre.prof@gmail.com \\ Maria Jamile da Silva \\ Centro Universitário Natalense (UNICEUNA), Rio Grande \\ do Norte. \\ mariajamiledasilva@gmail.com
}

\begin{abstract}
RESUMO: Este trabalho apresenta como tema central o estudo dos regimes de aproveitamento dos recursos minerais brasileiros sob a luz do direito minerário e tem como objetivo geral conceituar cada um desses regimes e encontrar quais os requisitos legais para a outorga dos mesmos. Quanto à metodologia aplicada para a realização do presente trabalho consistiu em pesquisa de natureza aplicada, com abordagem hipotético-dedutiva e qualitativa, com o objetivo descritivo e de propor avaliação formativa, pesquisas bibliográficas, documentais e legislações tanto no meio impresso quanto no meio eletrônico, além de estudo de caso. Para tanto, faz-se no primeiro capítulo uma introdução ao direito ambiental, partindo do meio ambiente como um direito difuso e posteriormente sobre seus principais princípios, como os princípios do meio ambiente ecologicamente equilibrado e o princípio a sadia qualidade de vida, trata ainda da influência dos recursos ambientais no direito minerário. Em seguida, no segundo capítulo, adentra-se de fato no direito minerário, tendo no primeiro tópico um escorço histórico do direito minerário e as Constituições brasileiras, o segundo tópico aborda o direito minerário brasileiro a partir da Constituição da República Federativa do Brasil, Código de Mineração e outras legislações que abordam o direito minerário. Por fim, o último tópico aduz sobre os regimes de aproveitamento dos recursos minerais no Brasil que são o regime de autorização, regime de concessão, regime de licenciamento, regime de permissão de lavra garimpeira e o regime de monopolização, aqueles previstos no Código de Mineração.
\end{abstract}

PALAVRAS-CHAVE: Direito Ambiental. Direito minerário. Regimes de aproveitamento. Recursos minerais.

\section{Mining Right in the light of mineral resources accepted in Brazil}

ABSTRACT: This study presents the central of the study of the regimes of the appropriate resources is of human in the light of the minimum mining and has to global to conceptualize each one regimes and what are legal requirements to grant them. Metadata is applied to the achievement of the present work in consistency with the research of nature, with the purpose of doing an opinion survey on the subject besides the case study. For most the party is the first to have the right environmental environment, and the acting of the environment the quality of nature environmental resources in the mining law. Then there is a group with no rights, no right to rights, no right, no right, no right, no right, no right, no right, no right to rights. other laws that deal with mining law. Finally, the last topic on profit-sharing schemes is not the concession regime, concession regime, concession regime, incentive grant scheme and monopoly regime, with the Mining Code in force. 
KEYWORDS: Environmental Law. Mining Law. Regimes of exploitation. Mineral resources.

\section{INTRODUÇÃ̃O}

O presente trabalho busca compreender a influência principiológica exercida pelo Direito Ambiental, disciplina jurídica que versa acerca da proteção conferida ao meio ambiente, sob o Direito Minerário, ramo jurídico que trata das normas e procedimentos relacionados aos recursos minerais. Buscando-se, ainda, analisar o Direito Minerário à luz dos regimes de aproveitamento dos recursos minerais no Brasil.

Nesse sentido, sabe-se que o Brasil possui em seu domínio territorial uma das maiores biodiversidades do planeta, tornando-se assim, um tema de grande relevância para o Direito, sendo fruto histórico da evolução humana. O Direito Ambiental é um ramo que cada vez mais ganha visibilidade tanto na esfera nacional como na internacional. A priori é necessário definir o Direito Ambiental como sendo direito difuso.

Cada vez mais se faz necessário regular as atividades dos seres humanos sobre o uso dos recursos naturais, assim foram criados uma série de princípios do Direito Ambiental e do Direito Minerário como também legislações cada vez mais rígida nesse sentido.

Sobre os capítulos a seguir, no primeiro capítulo abordaremos o Direito Ambiental como direito difuso e a proteção dos Recursos Naturais, previsto na Constituição da República Federativa do Brasil de 1988.

Adiante, passaremos aos princípios do Direito Ambiental, que podem estar expressos ou não na Carta Magna. Tendo como seu principal princípio o do meio ambiente ecologicamente equilibrado que trata sobre a garantia do direito à vida e sobre a responsabilidade com as gerações futuras, como o próprio nome do princípio sugere, uso equilibrado do meio ambiente. Sobre o princípio da sadia qualidade de vida que é considerado indispensável para a proteção e preservação da dignidade da pessoa humana.

No que concerne aos princípios do poluidor-pagador e do usuário-pagador, fez-se necessário diferenciar um do outro, pois apesar do nome, enquanto um é responsável pela restituição dos custos sociais dos danos causados por sua atividade, o outro não é necessário o dano para o pagamento da utilização do recurso natural.

Sobre os recursos ambientais e o direito minerário os mesmos podem ser colocados em dois grupos, onde os minérios estão classificados como não-renováveis.

Apresenta-se a história do Direito Minerário no Brasil a partir das Constituições brasileiras, tendo início ainda no Brasil Colônia, passando por uma série de mudanças até a Constituição Federal de 1988.

As mudanças no setor minerário a partir do novo Código de Mineração são abordadas neste trabalho, como também a criação da Agência Nacional de Mineração.

Para entender-se a importância do Direito Minerário e de sua legislação, foi necessário abordar o caso do maior desastre ambiental do Brasil e qual o impacto no novo Código de Mineração. Destarte, abordaremos os regimes de aproveitamento do Direito Minerário, previsão legal, e requisitos. 


\section{MEIO AMBIENTE NA ORDEM CONSTITUCIONAL E SUA INFLUÊN- CIA NA DISCIPLINA DOS RECURSOS MINERAIS}

\subsection{Meio ambiente como direito difuso}

O Direito Ambiental é considerado um ramo autônomo, possuindo princípios próprios e atuação direta do Estado nas questões ambientais. A lei $n^{\circ}$ 6938/1981 conceitua o meio ambiente como um "conjunto de condições, leis, influências e interações de ordem física, química e biológica, que permite, abriga e rege a vida em todas as suas formas" (art. $3^{\circ}, \mathrm{I}$ ) impulsionando a tutela dos direitos coletivos.

O Brasil possui em seu domínio territorial uma das maiores biodiversidades do planeta, e tornando-se assim, um tema de grande relevância para o Direito, sendo fruto histórico da evolução humana. Trata-se então da atuação de interesses difusos, ou seja, abstratos, sendo o destinatário um intermediário e não sendo possível identificar aquele o qual será o último beneficiário da proteção ambiental. Nesse sentido, nas palavras de Führer e Milaré1, a proteção dos interesses difusos, os quais se encontram significativamente presente nos temas concernentes ao meio ambiente, não estão atrelados a um titular individualizado, mas sim à toda uma coletividade e, ao mesmo tempo, a cada um de seus integrantes. Assim, tão logo que a doutrina passou a concentrarse nesse tema, consagrou-se a denominada terceira geração de direitos, em prosseguimento à primeira e segunda geração que, respectivamente, contemplavam os direitos individuais e os direitos sociais.

A Constituição da República Federativa do Brasil (CF/88)², estabelece em seu artigo 225 as diretrizes de preservação e proteção dos recursos naturais e ainda, definiu o meio ambiente como um bem de uso comum da sociedade comum:

Art. 225. Todos têm direito ao meio ambiente ecologicamente equilibrado, bem de uso comum do povo e essencial à sadia qualidade de vida, impondo-se ao poder público e à coletividade o dever de defendê-lo e preservá-lo para as presentes e futuras gerações.

Trata-se de direito fundamental de terceira geração, sendo relacionados com os chamados direitos de solidariedade ou fraternidade, buscando um meio ambiente ecologicamente equilibrado, como assim dispõe a decisão do Supremo Tribunal Federal (STF) sobre o julgamento do Mandado de Segurança (MS) no $22.164^{3}$.

$\mathrm{O}$ direito ambiental engloba quatro eixos, sendo o primeiro denominado meio ambiente natural, que é composto por elementos corpóreos e incorpóreos previstos no artigo 225, caput, §

1 FÜHRER, Maximilianus C. A.; MILARÉ, Édis. Manual de direito público e privado. 17. ed. São Paulo: RT, 2009, p. 315.

2 BRASIL.Constituição (1988). Constituição da República Federativa do Brasil. Brasília: Senado, 1988.

3 O direito à integridade do meio ambiente - típico direito de terceira geração - constitui prerrogativa jurídica de titularidade coletiva, refletindo, dentro do processo de afirmação dos direitos humanos, a expressão significativa de um poder atribuído, não ao indivíduo identificado em sua singularidade, mas, num sentido verdadeiramente mais abrangente, à própria coletividade social. Enquanto os direitos de primeira geração (direitos civis) - realçam o princípio da liberdade, e os direitos de segunda geração (direitos econômicos, sociais e culturais) -que se identificam com as liberdades positivas, reais ou concretas - acentuam o princípio da igualdade, os direitos de terceira geração, que materializam poderes de titularidade coletiva atribuídos genericamente a todas as formações sociais, consagram o princípio da solidariedade e constituem um momento importante no processo de desenvolvimento, expansão e reconhecimento dos direitos humanos, caracterizados, enquanto valores fundamentais indisponíveis, pela nota de uma essencial inexauribilidade. Supremo Tribunal Federal - STF sobre o julgamento do MS n ${ }^{\circ}$ 22.164. Rel. Min. Celso de Mello, Pleno, em 30/11/1995. 
$1^{\circ}$, I e II da CF/88. O segundo eixo refere-se ao meio ambiente artificial, que diz respeito ao meio ambiente urbano, as cidades e tem previsão nos artigos 225, 182 e 21, XX da CF/88. O terceiro eixo versa sobre o viés do direito cultural e do direito ambiental, abrangendo seus costumes e evolução mencionado na $\mathrm{CF} / 88 \mathrm{em}$ seu artigo 216. O último eixo do direito ambiental diz respeito ao trabalho, evidenciado no artigo $7^{\circ}$, XXII e 200, VIII ambos da CF/88.

Portanto, o direito ambiental possuí cinco características fundamentais, sendo a primeira característica o interesse difuso aludido no artigo 81 da Lei $n^{\circ} 8.078 / 1990$ onde disciplina in verbis "interesses ou direitos difusos assim entendidos para efeitos desse Código, os transindividuais, de natureza indivisível, de que sejam titulares pessoas indeterminadas e ligadas por circunstâncias de fato"4. A segunda característica é a metaindividualidade, que são aqueles interesses pertencentes a um grupo. Celso Fiorillo cita que "ultrapassam o limite da esfera de direitos e obrigações de cunho individual ${ }^{5}$."

\subsection{Principiologia do direito ambiental}

O direito ambiental é regido por leis, costumes, jurisprudências, doutrinas e por princípios que servem para salvaguardar o meio ambiente. Nesse liame, Milaré ${ }^{6}$ ressalta que o Direito Positivo, cuja construção ocorre de forma científica ao longo dos períodos e diante dos diversos fenômenos sociais, é responsável pela regulação das sociedades, sendo que, de forma semelhante, a mesma cientificidade do saber jurídico está presente no processo de criação dos princípios fundamentais do Direito Ambiental. Além disso, é possível afirmar, pelas mesmas razões, que os princípios norteadores dessa disciplina jurídica são dinâmicos e projetivos, haja vista que devem acompanhar as mudanças sociais introduzidas a cada geração.

Os princípios são elencados como normas jurídicas, os quais, conforme Amado ${ }^{7}$, devem ser compreendidos como normas norteadoras do sistema jurídico, possuindo um caráter de abstração, generalização e indeterminação superior às regras, haja vista que não visam a regular diretamente situações fáticas, algo que implica na impossibilidade de sua aplicação concreta.

Para Leme Machado ${ }^{8}$, os princípios que regem o direito ambiental são: princípio do direito ao meio ambiente equilibrado, princípio do direito à sadia qualidade de vida, princípio do acesso equitativo aos recursos naturais, princípio do usuário-pagador e do poluidor pagador, princípio da prevenção, princípio da reparação, princípio da informação e o princípio da obrigatoriedade da intervenção do poder público.

4 BRASIL. Lei n. 8.078, de 11 de setembro de 1990. Dispõe sobre a proteção do consumidor e dá outras providências. Disponível em: http://www.planalto.gov.br/ccivil 03/leis/18078.htm. Acesso em: 05/12/2018

5 FIORILlO. Celso Antônio Pacheco. Curso de direito ambiental brasileiro. 8, ed. rev., atual, e ampl. São Paulo: Saraiva. 2007. p. 6-7.

6 MILARÉ, Edis. Direito do Meio Ambiente. $7^{\text {a }}$ ed., revista, atual. e ampliada. São Paulo: Revista dos Tribunais, 2010.

7 AMADO. Frederico Augusto Di Trindade. Direito ambiental esquematizado. 2. ed, São Paulo: método, 2011 , p.39.

8 MACHADO. Paulo Affonso Leme. Direito ambiental brasileiro, 17. ed., rev. atual. e ampl. São Paulo: Malheiros. 2011. p. 62. 


\subsubsection{Princípio do meio ambiente ecologicamente equilibrado como direito} fundamental da pessoa humana

Tendo como seu princípio constitucional geral o princípio do meio ambiente ecologicamente equilibrado onde versa sobre o reconhecimento do direito à vida e fixa a responsabilidades desta geração para com as gerações futuras. Encontra-se inserido no caput do artigo 225 do texto maior. Esse reconhecimento como direito constitucional é uma conquista recente da sociedade brasileira9.

Durante o Fórum de Justiça do BRICS ${ }^{10}$ na cidade de Sanya, China em 2015 o Ministro do Supremo Tribunal Federal, Ricardo Lewandowsky, salientou ${ }^{11}$ :

O equilíbrio ambiental está consagrado na Constituição Federal de 1988 como um
direito de todo cidadão, ao estabelecer, em seu artigo 225, que todos têm direito ao
meio ambiente ecologicamente equilibrado, bem de uso comum do povo e essencial
à sadia qualidade de vida, impondo-se ao Poder Público e à coletividade o dever de
defendê-lo e preservá-lo para as presentes e futuras geraçães.

Paulo Affonso Leme Machado, em sua obra intitulada Direito Ambiental Brasileiro ${ }^{12}$, cita que ter direito ao meio ambiente ecologicamente equilibrado equivale a afirmar que há um direito que não se desiquilibre significativamente o meio ambiente.

Por sua vez, Thomé ${ }^{13}$, estabelece que tal princípio não é aplicado em qualquer situação de perigo de dano e sim na certeza cientifica do impacto ambiental de atividade. Impondo adesão de medidas preventivas hábeis a minimizar ou eliminar os efeitos negativos de uma atividade sobre o ecossistema.

Em suma, o princípio do direito ao meio ambiente ecologicamente equilibrado pode ser considerado pelo ordenamento jurídico, como um direito de terceira dimensão, sendo esse fundamental para a dignidade da pessoa humana. Pode ser tutelado por meio de uma Ação civil pública onde, a responsabilização dos danos causados é objetiva, ou seja, independe de culpa do poluidor/pagador.

\subsubsection{Princípio do direito à sadia qualidade de vida}

Endossa ainda o rol dos princípios do direito ambiental o princípio do direito à sadia qualidade de vida. Tal princípio é indispensável para a proteção e preservação do princípio da dignidade da pessoa humana.

9 ANTUNES. Paulo de Bessa. Direito Ambiental, 14. ed., São Paulo: Atlas, 2012. p.61.

${ }^{10}$ Bloco de Países composto por Brasil, Rússia, Índia, China e África do Sul.

${ }^{11}$ BRASIL. Supremo Tribunal Federal. Notícias STF. Na China, ministro Lewandowski destaca papel do judiciário na proteção ambiental. Disponível em: www.stf.jus.br/portal/cms/verNoticiaDetalhe.asp?idConteudo Acesso em: 13 de maio de 2019.

12 MACHADO. Paulo Affonso Leme. Direito ambiental brasileiro, 17. ed., rev. atual. e ampl. São Paulo: Malheiros. 2011. p. 62.

${ }^{13}$ SILVA. Romeu Faria Thomé da. Manual de direito ambiental. 7. ed., rev. atual. e ampl. Salvador: Jus podivm. 2017. p. 56. 
Fiorillo salienta que o bem ambiental é aquele "que tem como característica constitucional mais relevante ser essencial à sadia qualidade de vida, sendo ontologicamente de uso comum do povo, podendo ser desfrutado por toda e qualquer pessoa dentro dos limites constitucionais" ${ }^{14}$.

O Ministro Luiz Fux durante a apreciação da Ação Direta de Inconstitucionalidade (ADI) $\mathrm{n}^{\mathrm{o}} 4.029$ estabelece que ${ }^{15}$ :

[...] o meio ambiente é um conceito hoje geminado com o de saúde pública, saúde de cada indivíduo, sadia qualidade de vida, diz a Constituição, é por isso que estou falando e saúde, e hoje todos nós sabemos que ele é imbricado, é conceitualmente geminado com o próprio desenvolvimento. Se antes nós dizíamos que o meio ambiente é compatível com o desenvolvimento, hoje nós dizíamos que o meio ambiente é compatível com o desenvolvimento, hoje nós dizemos, a partir da Constituição, tecnicamente, que não pode haver desenvolvimento senão com o meio ambiente ecologicamente equilibrado. A geminação do conceito me parece de rigor técnico, porque salta da própria Constituição Federal.

A Conferência das Nações Unidas sobre o Meio Ambiente de $1972^{16}$ na Declaração de Estocolmo evidenciou-se em seu princípio número 1 que o homem tem direito fundamental a "[...] adequadas condições de vida, em um meio ambiente de qualidade[...]" ${ }^{17}$. Estabelece Leme Machado que "a qualidade de vida é um elemento finalista do Poder Público, onde se unem a felicidade do indivíduo e o bem comum, com fim de superar a estreita visão quantitativa, antes expressa no conceito de nível de vida" ${ }^{18}$.

Em síntese, quando falamos em direito à sadia qualidade de vida não se deve limitar apenas a saúde física de um indivíduo, deve-se levar em conta os elementos da natureza, a fim de mesurar sua vitalidade e possíveis riscos à saúde dos seres humanos.

\subsubsection{Princípio do acesso equitativo aos recursos naturais}

O princípio do acesso equitativo garante que todos utilizem de forma equilibrada os recursos ambientais. $\mathrm{O}$ direito ambiental tem como dever estatuir um conjunto de regras a fim de

${ }^{14}$ FIORILLO. Celso Antônio Pacheco. Curso de direito ambiental brasileiro. 8. Ed., rev., atual. e ampl. São Paulo: saraiva. 2007, p.173.

15 BRASIL. Supremo Tribunal Federal. Acórdão proferido em Ação Direta de Inconstitucionalidade N ${ }^{\circ}$ 4.029/AM. Ação Direta de Inconstitucionalidade. Lei Federal No 11.516/07. Criação do Instituto Chico Mendes de Conservação da Biodiversidade. Legitimidade da Associação Nacional dos Servidores do IBAMA. Entidade de Classe de Âmbito Nacional. Violação do art. 62, caput e $§ 9^{\circ}$, da Constituição. Não emissão de parecer pela Comissão Mista Parlamentar. Inconstitucionalidade dos artigos $5^{\circ}$, caput, e $6^{\circ}$, caput e parágrafos $1^{\circ}$ e $2^{\circ}$, da Resolução $N^{\circ} 1$ de 2002 do Congresso Nacional. Modulação dos Efeitos Temporais da Nulidade (Art. 27 da Lei 9.868/99). Ação Direta Parcialmente Procedente. Órgão Julgador: Tribunal Pleno. Relator: Ministro Luiz Fux. Julgado em 08 mar. 2012. Disponível em: http:// portal.stf.jus.br/. Acesso em: 13 maio 2019.

16 Fórum das Nações Unidas sobre o meio ambiente de 1972. Declaração de Estocolmo. Disponível em: http://www. direitoshumanos.usp.br/index.php/meio-ambiente/declaracao-de-estocolmo-sobre-o-ambiente-humano.html. Acesso em 13 maio 2019.

${ }^{17}$ Princípio 1. Declaração de Estocolmo. O homem tem o direito fundamental à liberdade, à igualdade e ao desfrute de condições de vida adequadas em um meio ambiente de qualidade tal que lhe permita levar uma vida digna e gozar de bem-estar, tendo a solene obrigação de proteger e melhorar o meio ambiente para as gerações presentes e futuras. A este respeito, as políticas que promovem ou perpetuam o apartheid, a segregação racial, a discriminação, a opressão colonial e outras formas de opressão e de dominação estrangeira são condenadas e devem ser eliminadas. Disponível em: http://www.direitoshumanos.usp.br/index.php/meio-ambiente/declaracao-de-estocolmo-sobre-o-ambiente-humano.html. Acesso em: 13 maio 2019.

${ }_{18}$ MACHADO. Paulo Affonso Leme. Direito ambiental brasileiro, 17. ed., rev. atual. e ampl. São Paulo: Malheiros. 2011. p. 61. 
estabelecer plausibilidade na utilização dos recursos minerais. Assim, conforme Machado ${ }^{19}$, fazse necessária a razoabilidade na utilização dos recursos, sendo que o desrespeito a tal critério pode implicar na proibição de sua utilização, independentemente de que se trate de um recurso que não é atualmente escasso.

O Princípio 5 da declaração de Estocolmo/72 expressa que "os recursos não renováveis do globo devem ser explorados de tal modo que não haja risco de serem exauridos e que as vantagens extraídas de sua utilização sejam partilhadas a toda a humanidade" 20 .

Os recursos naturais ficam sobre o comando de chefes de governo, sendo limitados ou não àqueles que habitam determinado território. O Princípio do acesso equitativo aos recursos naturais busca a harmonia no direito de usufruir esses recursos.

\title{
1.2.4. Princípios do poluidor pagador e do usuário pagador
}

Outros dois princípios importantes para o direito ambiental são os Princípios do poluidor pagador e do usuário pagador. Ressalte-se que estes são os princípios de grande controvérsia na seara ambiental por tratarem de questões financeiras.

O primeiro princípio consiste na obrigação do poluidor em assumir os custos da reparação do dano por ele causado e que esteja vinculado ao meio ambiente; este princípio foi consagrado por meio do ECO- $92^{21}$ :

\begin{abstract}
As autoridades nacionais devem esforçar-se para promover a internalização dos custos de proteção do meio ambiente e o uso dos instrumentos econômicos, levando-se em conta o conceito de que o poluidor deve, em princípio, assumir o custo da poluição, tendo em vista o interesse público, sem desvirtuar o comércio e os investimentos internacionais.
\end{abstract}

No que consiste a $\mathrm{CF} / 88$, a mesma traz em seu texto os seguintes termos: "Aquele que explorar recursos minerais fica obrigado a recuperar o meio ambiente degradado, de acordo com solução técnica exigida pelo órgão público competente, na forma da lei”"22.

Cabe destacar os itens do documento INFORMAÇÕES n.00374/2018/PROT/PFEIBAMA-RO/PGF/AGU assinado pelo Procurador Federal Kleberson Kaefer Kuhn, verbis ${ }^{23}$ :

1. Em complemento ao capítulo "DA RESPONSABILIDADE DO PRÓPRIO POLUIDOR EM REPARAR O DANO AMBIENTAL" seguem as seguintes informações:

2. Segundo o princípio do poluidor-pagador deverá o empreendedor responder pelos custos sociais da degradação causada por sua atividade impactante, devendo-se agregar esse valor no custo produtivo da atividade, para se evitar que se privatizem os

${ }^{19}$ MACHADO. Paulo Affonso Leme. Direito ambiental brasileiro, 17. ed., rev. atual. e ampl. São Paulo: Malheiros. 2011. p. 67.

${ }^{20}$ Princípio 5.Fórum das Nações Unidas sobre o meio ambiente de 1972. Declaração de Estocolmo. Disponível em: http://www.direitoshumanos.usp.br/index.php/meio-ambiente/declaracao-de-estocolmo-sobre-o-ambiente-humano. html. Acesso em 13 maio 2019

${ }^{21}$ NORMA PRINCÍPIO No 16, Conferência das Nações Unidas sobre o Meio Ambiente e o Desenvolvimento, 1992. Disponível em: www.meioambiente.pr.gov.br/Declaracao Rio_Meio Ambiente Desenvolvimento. Acesso em: 14 maio 2019.

${ }^{22} \S 2^{\circ}$, artigo.225, Constituição da República Federativa do Brasil, 1988

23 SAPIENS. Sistema AGU de inteligência jurídica. gerenciador eletrônico de documentos (GED), híbrido, que possui recursos de apoio para a produção de conteúdo e controle de fluxo de trabalho, focado na integração com os sistemas informatizados do Poder Judiciário e do Poder Executivo. Disponível em: www.sapiens.agu.gov.br. Acesso em: 15 maio 2019. 
lucros e se socializem os prejuízos ambientais, que também deverão ser internalizados (internalização das externalidades negativas).

Através desse entendimento, pessoas físicas e jurídicas causadoras de algum dano de poluição, sendo de direito público ou privado tem obrigação de pagar os custos das medidas adotadas necessárias para sanar ou reduzir a contaminação causada por elas. Não se trata de sair poluindo indiscriminadamente para pagar depois, no entendimento de Marcelo Abelha Rodrigues "o axioma poluidor-pagador não pode ser interpretado ao pé da letra, tendo em vista que não traduz a ideia de "pagar para poluir", e também porque seu alcance é absurdamente mais amplo do que a noção meramente repressiva que possui" ${ }^{24}$. Desta forma, o pagamento é pelo uso excessivo do recurso e não por danos causados.

O princípio do usuário pagador não se confunde com o princípio do poluidor pagador, apesar do nome. Enquanto no princípio do poluidor pagador, o poluidor é responsável pelos custos sociais dos danos causados pela sua atividade, o princípio do usuário pagador significa que as pessoas que utilizem recursos naturais devem pagar por sua utilização mesmo que não haja poluição.

Conforme Beltrão, o Princípio do Usuário pagador "consiste na cobrança de um valor econômico pela utilização de um bem ambiental. Diferentemente do princípio do poluidor-pagador, que tem uma natureza reparatória e punitiva" 25 .

Nesse mesmo sentido, Machado destaca que “o princípio do usuário-pagador não é uma punição, pois, mesmo inexistindo qualquer ilicitude no comportamento do pagador, ele pode ser implementado" 26 .

Apesar de não possuir expressa previsão na legislação, o Supremo Tribunal Federal já reconheceu a existência do Princípio do usuário pagador por meio da ADI 3.378, vejamos ${ }^{27}$ :

\begin{abstract}
AÇÃO DIRETA DE INCONSTITUCIONALIDADE. ART. 36 E SEUS $\S \S 1^{\circ}, 2^{\circ} \mathrm{E}$ $3^{\circ}$ DA LEI N ${ }^{\circ}$ 9.985, DE 18 DE JULHO DE 2000. CONSTITUCIONALIDADE DA COMPENSAÇÃO DEVIDA PELA IMPLANTAÇÃO DE EMPREENDIMENTOS DE SIGNIFICATIVO IMPACTO AMBIENTAL. INCONSTITUCIONALIDADE PARCIAL DO $\S 1^{\circ}$ DO ART. 36. 1. O compartilhamento-compensação ambiental de que trata o art. 36 da Lei ${ }^{\circ} 9.985 / 2000$ não ofende o princípio da legalidade, dado haver sido a própria lei que previu o modo de financiamento dos gastos com as unidades de conservação da natureza. De igual forma, não há violação ao princípio da separação dos Poderes, por não se tratar de delegação do Poder Legislativo para o Executivo impor deveres aos administrados. 2. Compete ao órgão licenciador fixar o quantum da compensação, de acordo com a compostura do impacto ambiental a ser dimensionado no relatório - EIA/RIMA. 3. O art. 36 da Lei $n^{\circ}$ 9.985/2000 densifica o princípio usuário-pagador, este a significar um mecanismo de assunção partilhada da responsabilidade social pelos custos ambientais derivados da atividade econômica. (...)5. O valor da compensação-compartilhamento é de ser fixado proporcionalmente ao impacto ambiental, após estudo em que se assegurem o contraditório e a ampla defesa. Prescindibilidade da fixação de percentual sobre os custos do empreendimento. 6. Ação parcialmente procedente.
\end{abstract}

${ }^{24}$ RODRIGUES. Marcelo Abelha. Instituições de direito ambiental. 5, ed. rev., atual. ampl. São Paulo: Max limoned, 2002. p. 138.

${ }^{25}$ BELTRÃO. Antônio Figueiredo Guerra. Curso de Direito Ambiental. 2, ed. red., atual. ampl. São Paulo: método. 2014. p. 35.

${ }^{26}$ MACHADO. Paulo Affonso Leme. Direito ambiental brasileiro, 17. ed., rev. atual. e ampl. São Paulo: Malheiros. 2011. p. 54.

${ }^{27}$ BRASIL. STF. ADI: 3378, DF, Relator: CARLOS BRITTO. Data de julgamento; 09 de abr de 2008. Tribunal do Pleno. Data de publicação: DJe-112 DIVULG 19 de jun de 2008. PUBLIC 20 de jun de 2008. EMENT VOL-0232402 PP- 00242. 
É necessário destacar que a Lei no 6.938/1981 (Lei de Política Nacional do Meio Ambiente $^{28}$ ) em seu artigo $4^{\circ}$, VII tem como objetivo determinar que os usuários contribuam para a utilização dos recursos naturais que tenham fins econômicos, como a água, por exemplo. A Lei Federal $n^{\circ}$ 9.433/1997 (Lei das águas ${ }^{29}$ ) trata da Política Nacional de Recursos Hídricos e baseiase nos fundamentos previstos no artigo $1^{\circ}$, nestes termos:
Art. $1^{\circ}$ A Política Nacional de Recursos Hídricos baseia-se nos seguintes fundamen- tos:
I- a água é um bem de domínio público;
II- a água é um recurso natural limitado, dotado de valor econômico;
III- em situações de escassez, o uso prioritário dor recursos hídricos é o consumo humano e a dessedentação de animais;
IV- a gestão dos recursos hídricos deve sempre proporcionar o uso múltiplo das águas;

Assim, os fundamentos previstos nos incisos I e II do artigo menciona a água como bem de domínio público dotado de valor econômico. No tocante a seção IV da Lei nº 9.433/1997 refere-se à cobrança do uso dos recursos hídricos. O artigo 19 dispõe:
Art. 19. A cobrança pelo uso de recursos hídricos objetiva:
I- reconhecer a água como bem econômico e dar ao usuário uma indicação de seu real valor;
II- incentivar a racionalização do uso da água;
III- obter recursos financeiros para o financiamento dos programas e intervenções contemplados nos planos de recursos hídricos.

Por fim, trata-se da finalidade de arrecadar recursos a serem revertidos ao meio ambiente, também funcionando como uma medida socioeducativa, inibindo o desperdício.

\subsubsection{Princípios da prevenção e da precaução}

Em todas as questões relacionadas ao Meio Ambiente, é necessário que haja uma pressuposição de que é mais eficaz tentar evitar o dano que tentar repará-lo. Partindo de tal premissa, o Princípio da Prevenção possui o propósito da cautela e tem previsão legal no artigo 225 da $\mathrm{CF} / 88$, surgindo de um prognóstico o qual exista conhecimento científico prévio dos riscos e impactos ambientais, podendo modificar os projetos, não causando danos ao meio ambiente.

Paulo de Bessa Antunes afirma que "o princípio da prevenção que informa tanto o licenciamento ambiental como os próprios estudos de impacto ambiental. Tanto um como outros são realizados sobre a base de conhecimentos já adquiridos" ${ }^{30}$.

\footnotetext{
${ }^{28}$ BRASIL. Lei n 6.938, de 31 de agosto de 1981. Dispõe sobre a política nacional do meio ambiente, seus fins e mecanismos de formulação e aplicação, e dá outras providências. Disponível em: www.planalto.gov.br/ccivil_03/leis/16938.htm. Acesso em: 16 de maio de 2019.

${ }^{29}$ BRASIL. Lei $n^{\circ} 9.433$, de 8 de janeiro de 1997. Institui a Política Nacional de Recursos Hídricos, cria o Sistema Nacional de Gerenciamento de Recursos Hídricos, regulamenta o inciso XIX do art. 21 da Constituição Federal, e altera $\mathrm{o}$ art. $1^{\circ}$ da Lei $n^{\circ} 8.001$, de 13 de março de 1990, que modificou a Lei ${ }^{\circ} 7.990$, de 28 de dezembro de 1989. Disponível em: www.planalto.gov.br/ccivil_03/leis/19433.htm. Acesso em: 31 de maio de 2019.

30 ANTUNES. Paulo de Bessa. Direito Ambiental, 14. ed., São Paulo: Atlas, 2012. p. 36.
} 
A Lei Complementar 140/2011 que regulamenta o art. 23, parágrafo único, incisos III, IV e VII da CF/88 trata da cooperação entre União, Estados, Distrito Federal e Municípios, como demonstra o art. $3^{\mathrm{o} 31}$ :

\begin{abstract}
Art. $3^{\circ}$. Constituem objetivos fundamentais da União, dos Estados, do Distrito Federal e dos Municípios, no exercício da competência comum a que se refere esta Lei Complementar:

I- proteger, defender e conservar o meio ambiente ecologicamente equilibrado, promovendo gestão descentralizada, democrática e eficiente;

II- garantir o equilíbrio do desenvolvimento socioeconômico com a proteção do meio ambiente, observando a dignidade da pessoa humana, a erradicação da pobreza e a redução das desigualdades sociais e regionais;

III- harmonizar as políticas e ações administrativas para evitar a sobreposição de atuação entre os entes federativos, de forma a evitar conflitos de atribuições e garantir uma atuação administrativa eficiente;

IV- garantir a uniformidade da política ambiental para todo o País, respeitadas as peculiaridades regionais e locais.
\end{abstract}

Com base nesse Princípio, pode-se impor ao empreendedor, quando se tratar de licenciamento ambiental, condicionantes com o intuito de impedir ou mitigar eventuais danos ao meio ambiente.

Por sua vez, o Princípio da Precaução não está expressamente previsto na Constituição Federal, porém, foi consagrado internacionalmente na Declaração do Rio, na ECO 92 como o princípio de $n^{\circ} 15$. Neste princípio, não há o conhecimento prévio dos riscos e impactos ambientais. Tem a finalidade de proteger o meio ambiente para as gerações presentes e futuras. Entende-se, por esse princípio, que não se deve licenciar uma atividade a qual não se tenha total convencimento de que ela não causará danos irreversíveis ao ambiente.

Apesar de não possuir expressa previsão na Carta Magna, tal princípio foi reconhecido no julgamento do Agravo Regimental em Medida Cautelar na Ação Cível Originária $n^{\circ} 876$ (ACO 876 MC-AGR), pelo Supremo Tribunal Federal ${ }^{32}$ :

\begin{abstract}
Agravo regimental. Medida liminar indeferida. Ação civil originária. Projeto de Integração do Rio São Francisco com as Bacias Hidrográficas do Nordeste Setentrional. Periculum in mora não evidenciado. 1. Como assentado na decisão agravada, a Ordem dos Advogados do Brasil - Seção da Bahia, AATR - Associação de Advogados de Trabalhadores Rurais no Estado da Bahia, GAMBA - Grupo Ambientalista da Bahia, IAMBA - Instituto de Ação Ambiental da Bahia, Associação Movimento Paulo Jackson - Ética, Justiça e Cidadania, PANGEA - Centro de Estudos Socioambientais e da AEABA - Associação dos Engenheiros Agrônomos da Bahia, não detêm legitimidade ativa para a ação prevista no art. 102, I, "f", da Constituição Federal. 2. A Licença de Instalação levou em conta o fato de que as condicionantes para a Licença Prévia estão sendo cumpridas, tendo o IBAMA apresentado programas e planos relevantes para o sucesso da obra, dos quais resultaram novas condicionantes
\end{abstract}

${ }^{31}$ BRASIL. Lei Complementar $n^{\circ}$ 140, de 8 de dezembro de 2011. Fixa normas, nos termos dos incisos III, VI e VII do caput e do parágrafo único do artigo 23 da Constituição Federal, para a cooperação entre a União, os Estados, o Distrito Federal e os Municípios nas ações administrativas decorrentes do exercício da competência comum relativas à proteção das paisagens naturais notáveis, à proteção do meio ambiente, ao combate à poluição em qualquer de suas formas e à preservação das florestas, da fauna e da flora; e altera a Lei nº 6.938, de 31 de agosto de 1981. Disponível em: www.planalto.gov.br/ccivil_03/leis/lcp/lcp140.htm. Acesso em: 31 de maio de 2019.

${ }^{32}$ BRASIL. STF. ACO 876 MC-AgR / BA - BAHIA AG.REG.NA MEDIDA CAUTELAR NA AÇÃO CÍVEL ORIGINÁRIA Relator(a): Min. MENEZES DIREITO. Julgamento: 19/12/2007. Órgão Julgador: Tribunal Pleno Publicação DJe-142 DIVULG 31-07-2008 PUBLIC 01-08-2008 EMENT VOL-02326- 01 PP-00044 RTJ VOL-00205-02 PP-00537. Disponível em: https://stf.jusbrasil.com.br/jurisprudencia/14723924/agregna-medida-cautelar-na-acao-civel-originaria-aco-876-ba. Acesso em: 31 maio 2019. 
para a validade da referida Licença de Instalação. A correta execução do projeto depende, primordialmente, da efetiva fiscalização e empenho do Estado para proteger o meio ambiente e as sociedades próximas. 3. Havendo, tão-somente, a construção de canal passando dentro de terra indígena, sem evidência maior de que recursos naturais hídricos serão utilizados, não há necessidade da autorização do Congresso Nacional. 4. O meio ambiente não é incompatível com projetos de desenvolvimento econômico e social que cuidem de preservá-lo como patrimônio da humanidade. Com isso, pode-se afirmar que o meio ambiente pode ser palco para a promoção do homem todo e de todos os homens. 5. Se não é possível considerar o projeto como inviável do ponto de vista ambiental, ausente nesta fase processual qualquer violação de norma constitucional ou legal, potente para o deferimento da cautela pretendida, a opção por esse projeto escapa inteiramente do âmbito desta Suprema Corte. Dizer sim ou não à transposição não compete ao Juiz, que se limita a examinar os aspectos normativos, no caso, para proteger o meio ambiente. 6. Agravos regimentais desprovidos.

Esse princípio encontra previsão nas resoluções do Conselho Nacional do Meio Ambiente - CONAMA, da Agência Nacional de Mineração - ANM e na legislação pátria infraconstitucional por meio da Lei $\mathrm{n}^{\mathrm{o}}$ 11.105/2005 (Lei de Biossegurança) em seu art. $1^{\mathrm{o}}$, que dispõe $\mathrm{e}^{33}$ :

Art. $1^{\circ}$ Esta Lei estabelece normas de segurança e mecanismos de fiscalização sobre a construção, o cultivo, a produção, a manipulação, o transporte, a transferência, a importação, a exportação, o armazenamento, a pesquisa, a comercialização, o consumo, a liberação no meio ambiente e o descarte de organismos geneticamente modificados- OGM e seus derivados, tendo como diretrizes o estimulo ao avanço cientifico na área de biossegurança e biotecnologia, a proteção à vida e à saúde, animal e vegetal, e a observância do princípio da precaução para a proteção do meio ambiente.

Essas normas estabelecem critérios e técnicas para a manipulação genética, com a finalidade de evitar danos ao Meio Ambiente e à saúde humana. O anexo I da resolução do CONAMA $n^{\circ} 237 / 97^{34}$ submete a utilização do patrimônio genético natural como uma atividade sujeita ao licenciamento ambiental, considerando como atividade potencialmente poluidora.

\subsection{Recursos ambientais e a influência no Direito Minerário}

Os recursos ambientais podem ser definidos como aqueles disponíveis na natureza de origem animal, vegetal ou mineral. Tem sua regulamentação na Lei $n^{\circ} 6.938$, de 31 de agosto de 1981 - art. $3^{\circ}$, V. que dispõ $\mathrm{e}^{35}$ :

Art. $3^{\circ}$ - Para os fins previstos nesta Lei, entende-se por: V - Recursos ambientais: a atmosfera, as águas interiores, superficiais e subterrâneas, os estuários, o mar territorial, o solo, o subsolo, os elementos da biosfera, a fauna e a flora. (Redação dada pela Lei $n^{\circ} 7.804$, de 1989)

${ }^{33}$ BRASIL. Lei $n^{\circ} 11.105$, de 24 de março de 2005. Regulamenta os incisos II, IV e V do $§ 1^{\circ}$ do art. 225 da Constituição Federal, estabelece normas de segurança e mecanismos de fiscalização de atividades que envolvam organismos geneticamente modificados - OGM e seus derivados, cria o Conselho Nacional de Biossegurança- CNBS, reestrutura a Comissão Técnica Nacional de Biossegurança - CTNBio, dispõe sobre a Política Nacional de Biossegurança - PNB, revoga a Lei $\mathrm{n}^{\circ} 8.974$, de 5 de janeiro de 1995, e a Medida Provisória $\mathrm{n}^{\circ} 2.191-9$, de 23 de agosto de 2001, e os arts. $5^{\circ}, 6^{\circ}, 7^{\circ}, 8^{\circ}, 9^{\circ}, 10$ e 16 da Lei $n^{\circ} 10.814$, de 15 de dezembro de 2003, e dá outras providências. Disponível em: www.planalto.gov.br/ccivil_03/_ato2004-2006/2005/lei/111105.htm. Acesso em: 31 de maio de 2019.

${ }^{34}$ Resolução no 237- CONAMA, de 19 de dezembro de 1997. Disponível em: http://extwprlegs1.fao.org/docs/pdf/ bra25095.pdf. Acesso em: 31 maio 2019.

35 BRASIL. Lei n 6.938, de 31 de agosto de 1981. Dispõe sobre a política nacional do meio ambiente, seus fins e mecanismos de formulação e aplicação, e dá outras providências. Disponível em: www.planalto.gov.br/ccivil_03/leis/ 16938.htm. Acesso em: 16 maio 2019. 
Posteriormente, a Lei n ${ }^{\circ}$ 9.985, de 18 de julho de 2000, inseriu o subsolo em sua definição de recursos ambientais ${ }^{36}$.

Os recursos naturais podem ser classificados em dois grupos: os recursos renováveis (florestas, solos) e não-renováveis (minerais) ${ }^{37}$. Os pertencentes ao segundo grupo são denominados por existir uma determinada quantidade fixa na crosta terrestre e para que haja renovação é necessário que ocorra processos geológicos, químicos e físicos que duram milhares de anos e ainda existe a possibilidade de exaustão ou esgotamento. Por essa razão, a importância do desenvolvimento sustentável.

Para Eliana Poveda ${ }^{38}$, é necessário o planejamento e controle do exercício da mineração, haja vista que os recursos minerais existentes não são renováveis e sequer infinitos. Por isso, deve-se programar o empreendimento minerário, sendo que, diante da exaustão do bem mineral ou da sua inviabilidade técnica ou econômica, pode haver o fechamento ou desativação do referido empreendimento.

Desta forma, observa-se que a autora destaca a independência da indústria mineral no que tange as atividades extrativistas.

O controle do exercício da mineração tem determinação expressa na $\mathrm{CF} / 88$ no parágrafo segundo do artigo 225. Tendo a mesma tutelado os recursos minerais como propriedade da União Federal, como também a condição de gestoras desses bens ambientais.

\section{DIREITO MINERÁRIO À LUZ DO REGIME EXPLORATÓRIO BRASI- LEIRO}

\subsection{Escorço histórico do Direito Minerário brasileiro e as Constituições brasileiras}

A história do Direito Minerário brasileiro inicia-se com a própria história do Brasil na segunda década. Após a chegada dos portugueses ao Brasil, foram editadas as Ordenações Manuelinas. ${ }^{39}$ Essas ordenações asseguravam à coroa portuguesa a posse de jazidas ${ }^{40}$ e garantia ao descobridor o direito à exploração mediante a quinta parte dos metais extraídos. Nesse sentido,

${ }^{36}$ BRASIL. Lei n 9.985 de 18 de julho de 2000. Regulamenta o artigo 225 , $\S 1^{\circ} \mathrm{Art}$. $2^{\circ}$ incisos I, II, III e IV da Constituição Federal, institui o sistema nacional de unidades de conservação da natureza e dá outras providências. Art. $2^{\circ}$ Para os fins previstos nesta Lei, entende-se por: IV - Recurso ambiental: a atmosfera, as águas interiores, superficiais e subterrâneas, os estuários, o mar territorial, o solo, o subsolo, os elementos da biosfera, a fauna e a flora; Disponível em: www.planalto.gov.br/ccivil 03/leis/19985.htm Acesso em: 16 de maio de 2019.

37 POVEDA. Eliane Pereira Rodrigues. A eficácia legal na desativação de empreendimentos minerários. São Paulo: Signus editora. 2007, p. 5.

${ }^{38}$ POVEDA. Eliane Pereira Rodrigues. A eficácia legal na desativação de empreendimentos minerários. São Paulo: Signus editora. 2007, p. 10.

39 São conhecidos com o nome de "Ordenações manuelinas" os três sistemas de preceitos jurídicos impressos, em cinco livros o primeiro, de 1512-13 (teve uma reedição com correções pontuais, em 1514); o segundo sistema, posterior a 1516 e anterior a 1520 (de que apenas se conhecem fragmentos recentemente descobertos que se encontram em restauro); e o terceiro sistema, de 1521 (com quatro edições e diferentes reimpressões de cada uma delas, entre 1521 e 1603). Constituem o primeiro grande conjunto legislativo e normativo do Portugal Quinhentista. Disponível em: www. bnportugal.gov.bt/ordenacoes manuelinas 500 anos depois=pt Acesso em: 21 maio 2019.

40 Jazida é toda massa individualizada de substância mineral ou fóssil, aforando à superfície ou existente no interior da terra que possua valor econômico. Disponível em: http://jus.com.br/artigos/59339/a-jazida. Acesso em: 22 maio 2019. 
Herrmann cita que "[...] pertenciam à Coroa portuguesa o ouro, a prata, o diamante, as gemas e alguns metais estratégicos. Todos os demais, a areia entre eles, não eram, por conseguinte, alcançados pela legislação central" ${ }^{\prime 1}$.

Com a promulgação da Constituição de 1891, primeira Constituição após a Proclamação da República, o Brasil passou por várias mudanças como a implantação da república federativa com governo centralizado e a divisão de Estados membros, divisão dos poderes em executivo, legislativo e judiciário e a determinação do voto universal masculino. No setor da mineração, trouxe disciplina própria sobre o sistema da propriedade minerária, unindo o domínio do subsolo ao do solo, ou seja, o direito de propriedade era visto como absoluto, pois oferecia ao titular o caráter de senhor sobre as minas que se encontravam em seu território com a ressalva de desapropriação por necessidade ou utilidade pública, sendo o proprietário, nesses casos, previamente indenizado. O Código Civil de 1916 corroborou essa sistemática em seu artigo $526^{42}$.

Posteriormente, com a Constituição de 1934, surgiu o sistema de concessão que vigora até os dias atuais. Os artigos 118 e 119 da referida Constituição expressa:

\begin{abstract}
Art. 118. As minas e demais riquezas do subsolo, bem como as quedas d'água, constituem propriedade distinta da do solo para efeito de exploração ou aproveitamento industrial.

Art. 119. O aproveitamento industrial das minas e das jazidas minerais, bem como das águas e da energia hidráulica, ainda que de propriedade privada, depende de autorização ou concessão federal, na forma da lei.

$\S 1^{\circ}$ As autorizações ou concessões serão conferidas exclusivamente a brasileiros ou a empresas organizadas no Brasil, ressalvada ao proprietário preferência na exploração ou coparticipação nos lucros
\end{abstract}

Portanto, o sistema de concessão consagrou o princípio da dualidade imobiliária, que estabelece que o solo e o subsolo pertencem ao superficiário, porém as riquezas minerais, presentes no solo ou subsolo, pertencem à União Federal.

A Constituição de 1937 manteve o sistema de concessão e, em seu artigo 143, distinguiu as riquezas do subsolo para efeitos de exploração ou aproveitamento industrial e, nesta última, firmou a dependência de autorização federal. No parágrafo primeiro do referido artigo, tratou-se da autorização, a qual deveria ser concedida a brasileiros ou a empresas constituídas por acionistas brasileiros, reservando-se, ao proprietário, a preferência na exploração ou na participação dos lucros.

Já a Constituição de 1946 extinguiu o direito do superficiário à participação nos lucros, mantendo o sistema de concessão e a prioridade ao proprietário do solo à exploração. $\mathrm{O}$ artigo 153 da Constituição de 1946 acrescentou, além dos recursos minerais, a dependência da autorização ou concessão federal para o aproveitamento das energias hidráulicas. Já o parágrafo primeiro do mencionado artigo trata das autorizações e concessões, as quais conferiam, exclusivamente, a brasileiros ou a sociedades organizadas no Brasil. Trata ainda sobre a prioridade do proprietário do solo à exploração.

\footnotetext{
${ }^{41}$ HERRMANN,H. A mineração sob a óptica legal. In: LINS, F. A. F.; LOUREIRO,F. E. V. L; ALBUQUERQUE, G. A. S. C. de. Brasil 500 anos - a construção do Brasil e da América Latina pela mineração: histórico, atualidades e perspectivas. Rio de Janeiro: CETEM/MCT, 2000. p. 21-34.

42 Artigo 526 do Código Civil de 1916. A propriedade do solo abrange a do que lhe está superior e inferior em toda a altura e em toda a profundidade, úteis ao seu exercício, não podendo, todavia, o proprietário opor-se a trabalhos que sejam empreendidos a uma altura ou profundidade tais, que não tenha ele interesse algum em impedi-los. Lei $\mathrm{n}^{\circ} 3.071$ de $1^{\circ}$ de janeiro de 1916. Disponível em: www.planalto.gov.br/ccivil_03/leis/13071.htm. Acesso em: 20 de maio de 2019.
} 
Diferente da Constituição de 1946, a Constituição de 1967 extinguiu o direito prioritário do proprietário do solo à exploração dos recursos minerais, consoante o artigo 161 e complemento no parágrafo primeiro, in verbis:

\begin{abstract}
Art. 161. As jazidas, minas e demais recursos minerais e os potenciais de energia hidráulica constituem propriedade distinta da do solo para o efeito de exploração ou aproveitamento industrial.

$\S 1^{\circ}$ A exploração e o aproveitamento das jazidas, minas e demais recursos minerais e dos potenciais de energia hidráulica dependem de autorização ou concessão federal, na forma da lei, dada exclusivamente a brasileiros ou a sociedades organizadas no País.
\end{abstract}

Nestes termos, o proprietário do solo passou a ter as mesmas condições que terceiros interessados, ou seja, pela antecedência no requerimento de pesquisa. Ressalva-se que a concessão era dada somente a brasileiros ou a sociedades organizadas no País.

Com o atual regime constitucional, $\mathrm{CF} / 88$, a mineração é tratada em diversos aspectos como o controle dos recursos minerais, competência e fiscalização dos recursos minerais, proteção ao meio ambiente e as normas de fruição.

Com a promulgação da $\mathrm{CF} / 88$, a questão dos recursos minerais foi ampliada e renovada, tratando do setor mineral direta ou indiretamente, passando a tratar questões de garimpos, mineração, meio ambiente, mineração em terras de fronteiras indígenas. Vejamos a seguir as principais mudanças previstas no texto da Carta Magna.

$\mathrm{O}$ artigo 20 da $\mathrm{CF} / 88$ remete à União Federal o domínio dos recursos minerais, incluindo o subsolo. O ministro do STF Celso de Mello, na decisão n. 140.254-7, classifica os bens minerais. Nestes termos ${ }^{43}$ :

\begin{abstract}
O sistema de direito constitucional positivo vigente no Brasil - fiel à tradição republicana iniciada com a Constituição de 1934 - instituiu verdadeira separação jurídica entre a propriedade do solo e a propriedade mineral (que incide sobre as jazidas, em lavra ou não, e demais recursos minerais existentes no imóvel) e atribuiu, à União Federal, a titularidade da propriedade mineral, para o específico efeito de exploração econômica e/ou de aproveitamento industrial. A propriedade mineral submete-se ao regime de dominialidade pública. Os bens que a compõem qualificam-se como bens públicos dominiais, achando-se constitucionalmente integrados ao patrimônio da União Federal.
\end{abstract}

A CF/88 trouxe entendimento e transparência no que concerne ao real detentor da propriedade e dos recursos minerais e não apenas a dualidade do solo e subsolo como as outras constituições brasileiras.

No que diz respeito a competência legislativa privativa, a CF/88 remete à União Federal essa atribuição em seu artigo 22, inciso XII, o qual dispõe que as jazidas, minas, outros recursos minerais e metalurgia. Já o parágrafo único do artigo mencionado autoriza os Estados, por meio de lei complementar, legislar sobre questões específicas das matérias relacionadas nos vinte e nove incisos do artigo 22.

$\mathrm{O}$ art.23 da CF/88 dispõe que "é competência comum da União, dos Estados, do Distrito Federal e dos Municípios: registrar, acompanhar e fiscalizar as concessões de direitos de pesquisa e exploração de recursos hídricos e minerais em seus territórios." Seguido do inciso XI do mesmo artigo. A ação conjunta das três esferas da Federação torna mais eficiente a administração

${ }^{43}$ BRASIL. STF. Ag. Reg. Em RE n 140.254-7. Rel. Min. Celso de Mello, DJ de 6-6-1997. Informativo STF $n^{\circ} 74$. Disponível em: www.stf.jus.br/portal/constituicao/artigoBd.as?item=1699. Acesso em: 20 de maio de 2019. 
dos recursos públicos. Cabe salientar que, aos Estados-Membros e aos Municípios, essa competência não é facultativa, ou seja, em caso de omissão, estarão descumprindo um dever constitucional.

Tratando do artigo 24 da CF/88, ou seja, da competência legislativa concorrente, a atribuição de legislar concorrentemente sobre as florestas, caça, pesca, fauna, conservação da natureza, defesa do solo e dos recursos naturais, proteção do meio ambiente e o controle da poluição compete à União, aos Estados e ao Distrito Federal. Desta forma, cabe à União a definição de normas gerais e aos Estados e Distrito Federal as normas particulares.

Destaca-se que os recursos minerais são de domínio da União Federal e ficam submetidos às normas que emanam do Congresso Nacional e sanção do Presidente da República, como dispõe o artigo 48, inciso V. Por outro lado, cabe ao Congresso Nacional autorizar, em terras indígenas, a exploração e o aproveitamento de recursos hídricos e a pesquisa de lavra de riquezas minerais por meio de decreto legislativo, não havendo participação do Presidente da República para sanção ou veto.

Conclui-se então que a história do direito minerário brasileiro se atrela à própria história do Brasil e das Constituições, tendo em vista a grande importância desse tema.

\subsection{Princípios do Direito Minerário}

Além dos princípios constitucionais do direito ambiental, fez-se necessária a implantação de princípios próprios do direito minerário.

Serra alude que "a importância de se conhecer os princípios que conduzem a legislação minerária, a fim de atender o sentido dela, aplicando-a de forma adequada" ${ }^{44}$.

O primeiro princípio a ser destacado trata-se do Princípio da supremacia do interesse público sobre o privado, tal princípio compõe a base do regime jurídico administrativo. Para a doutrina, esse princípio significa que os interesses da coletividade devem prevalecer sobre os do particular. Para a administração conseguir cumprir seus objetivos previstos na CF/88 ou nas leis, é necessário que a administração possua mais poderes que o particular. Ademais, segundo Feigelson $^{45}$, a supremacia do interesse público sobre o privado, implica que interesses divergentes advindos deste não impeçam a concretização do empreendimento minerário, posto que, na ausência desse princípio, a atividade de mineração poderia ser inviabilizada, implicando em graves danos à economia brasileira.

Segundo Serra, "a pesquisa e a lavra dos recursos minerais sempre terão que estar sendo realizadas de forma a atender o interesse público, devem ser cessadas, sobrepondo-se aos interesses do minerador" $" 46$.

A doutrina costuma separar esse princípio em primário e secundário. O primário é aquele que, de fato, justifica a existência da administração pública, visando o bem da coletividade. $\mathrm{O}$ secundário, por sua vez, busca o benefício do próprio Estado.

\footnotetext{
${ }^{44}$ SERRA. Silvia Helena. Direitos minerários: formação, condicionantes e extinção. São Paulo: Signus Editora, 2000. p.29.

${ }^{45}$ FEIGELSON. Bruno. Curso de Direito Minerário. $2^{\text {a }}$ Ed. São Paulo: Saraiva, 2014. p. 88.

${ }^{46}$ SERRA. Silvia Helena. Direitos minerários: formação, condicionantes e extinção. São Paulo: Signus Editora, 2000. p.27.
} 
O princípio da destinação do bem ao uso geral é fruto do princípio anterior e aduz que o bem mineral de domínio coletivo tem que ser aproveitado exclusivamente pela coletividade. Serra afirma que "a atividade minerária tem um duplo escopo: aproveitar economicamente o recurso mineral e, sobretudo, colocá-lo à disposição da sociedade" ${ }^{\$ 7}$. Por esse princípio, justificase o fato de a administração pública deter o poder discricionário de recusa da outorga entre outros.

O princípio do resultado global não se limita a fazer o cálculo do bônus e do ônus financeiro e ambiental; muito mais do que isso, ele avalia o ônus e o bônus social em todas as suas variáveis. Segundo Serra, "somente mediante uma avaliação sistêmica de todos eles é que o poder público poderá avaliar a viabilidade do empreendimento mineiro, analisando o resultado global" 48 .

O princípio da recuperação do meio ambiente degradado obriga que o novo empreendimento inicie seus trabalhos com o plano de recuperação da área que ficará degradada com a exploração econômica da jazida. Serra alude que "esse princípio significa que, na mineração, se a recuperação é uma exigência, a modificação do status quo ambiental é uma necessidade"49.

Este princípio é de grande relevância para a atividade minerária, pois é impossível recuperar a área da jazida no decorrer da exploração mineral. A CF/88 no parágrafo segundo do artigo 225, concede, ao mesmo tempo, uma garantia ao minerador e lhe impôs também uma obrigação.

O princípio da confiança legítima, de acordo com Feigelson, “é aplicado as questões em que não há expectativa de direitos, ou seja, há apenas uma promessa. Pode ser aplicado na relação entre DNPM e minerador, por exemplo"50. Trata-se do princípio que visa assegurar a permanência das regras proporcionando ao administrado confiança nas mesmas.

Portanto podemos concluir que os novos instrumentos normativos deverão passar por um período de adaptação, não sendo possível sua repentina alteração.

\subsection{Direito Minerário brasileiro}

Como já mencionado anteriormente, o direito minerário é constituído por um grupamento de regras jurídicas, as quais relaciona-se com o Estado, mineradores e terceiros interessados, fixando direitos e obrigações nestas relações.

No ano de 1967, foi criado o Código de Mineração ${ }^{51}$, que regula os direitos sobre as massas individualizadas de substâncias minerais ou fósseis, encontradas no solo ou subsolo que formam os recursos minerais brasileiros; regime de reaproveitamento; fiscalização, pesquisa e de outros aspectos da indústria mineral.

\footnotetext{
${ }^{47}$ SERRA. Silvia Helena. Direitos minerários: formação, condicionantes e extinção. São Paulo: Signus Editora, 2000. p.29.

48 SERRA. Silvia Helena. Direitos minerários: formação, condicionantes e extinção. São Paulo: Signus Editora, 2000. p.27.

49 Ibid, p. 28.

${ }^{50}$ FEIGELSON. Bruno. Curso de Direito Minerário. $2^{\text {a }}$ Ed. São Paulo: Saraiva, 2014. p. 88.

${ }^{51}$ BRASIL. Decreto- Lei no 227 , de 28 de fevereiro de 1967. Dá nova redação ao Decreto-Lei n $^{\circ} 1.985$, de 29 de janeiro de 1940 (código de minas). Disponível em: www.planalto.gov.br/ccivil/decreto-lei/del0227.htm. Acesso em: 25 de maio de 2019.
} 
Em 12 de junho de 2018 publicou-se no Diário Oficial da União o Decreto $\mathrm{n}^{\circ} 9.406^{52}$. Esse decreto regulamenta o Código de Mineração, trazendo diversas alterações no setor minerário, que serão demonstradas no próximo tópico.

\subsubsection{Mudanças no setor minerário a partir do novo Código de Mineração}

Dentre as principais alterações do Decreto 9.406/2018, destacam-se os tópicos seguintes.

$\mathrm{O}$ artigo segundo que inseriu expressamente o interesse nacional e a utilidade pública como fundamentos para o desenvolvimento da mineração.

Já o caput artigo quinto incluiu o fechamento de mina como um estágio da atividade mineral. O parágrafo segundo do mesmo artigo prevê expressamente a obrigação do minerador pela recuperação ambiental das áreas degradadas.

Foi incluído no quarto parágrafo do artigo nono a necessidade de atendimento aos padrões internacionais para cálculo dos recursos e reservas. O parágrafo sétimo do mesmo artigo manifesta a possibilidade de realização de pesquisa secundária posterior a restituição do trabalho de pesquisa, podendo ser incluídos os resultados no plano de aproveitamento econômico, porém não sendo possível a utilização para fins de retificação do relatório de pesquisa.

Sobre o aproveitamento de rejeito estéril e resíduos da mineração, o parágrafo segundo do artigo décimo dispõe sobre a possibilidade de regulamentação, sendo os mesmos estimulados pelo Ministério de Minas e Energia e pela Agência Nacional de Mineração através de aditamento ao título por meio de procedimento simplificado.

O parágrafo segundo do artigo vinte e um trata das prorrogações consecutivas do prazo de autorização de pesquisa, nas hipóteses de falta de acesso à área de pesquisa ou ainda na falta de assentimento ou licença do órgão ambiental exclusivamente. É necessário que o titular demonstre documentos que confirmem que o mesmo atendeu às diligências e as notificações no curso do processo, seja determinada por avaliação judicial ou por órgão ambiental. Também se faz necessário que o titular demonstre que não contribuiu, por ação ou omissão, para a falta de acesso a área de pesquisa ou na expedição dos documentos necessários para assentamento ou da licença ambiental. O parágrafo terceiro do mesmo artigo prevê a prorrogação automática enquanto a análise do pedido de prorrogação estiver pendente.

O caput do artigo vinte e dois trata da possibilidade de renúncia parcial do alvará de pesquisa. A renúncia em partes ou total se torna eficaz na data do protocolo do instrumento de renúncia.

No tocante ao relatório final de pesquisa, prevê o parágrafo terceiro do artigo vinte e cinco que a não entrega do relatório final de pesquisa ao final do prazo de vigência da autorização ou de sua prorrogação coloca a área em disponibilidade.

Fica o requerente da lavra obrigado a comprovar a solicitação de licença ambiental em prazo de sessenta dias e de que o pedido está em andamento e que as medidas necessárias estão sendo devidamente tomadas para a obtenção da licença a cada seis meses. Assim dispõe o quarto parágrafo do artigo trinta e um.

\footnotetext{
52 BRASIL. Decreto $n^{\circ}$ 9.406, de 12 de junho de 2018. Regulamenta o Decreto-Lei $\mathrm{n}^{\circ} 227$, de 28 de fevereiro de 1967 , a lei ${ }^{\circ} 6.567$, de 24 de setembro de 1978 , a Lei $n^{\circ} 7.805$, de 18 de julho de 1989 , e a Lei ${ }^{\circ} 13.575$, de 26 de dezembro de 2017. Disponível em: www.planalto.gov.br/ccivil_03/_Ato2015-2018/2018/Decreto/D9406.htm. Acesso em: 27 de maio de 2019.
} 
Sobre a Taxa Anual por Hectare (TAH), o artigo quarenta e oito dispõe que poderá ser fixada em valores progressivos em função da substância mineral objetivada, da extensão e da localização da área, e de outras condições.

Conclui-se que essas mudanças presentes no Código de Mineração buscam o desenvolvimento de novas tecnologias, sustentabilidade e a obrigação do minerador com o meio ambiente, tornando as regras mais rígidas, incentivando o desenvolvimento desse setor.

\subsubsection{Criação da Agência Reguladora}

A Lei no 13.575/2017 criou a Agência Nacional de Mineração vinculada ao Ministério de Minas e Energia e que tem como propósito suceder o Departamento Nacional de Produção Mi-

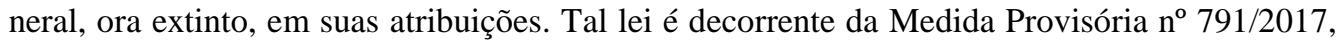
tendo sido apresentada em julho de 2017 e aprovada pelo Senado Federal em novembro do mesmo ano.

A Agência Nacional de Mineração possui o intuito de gerenciar os recursos minerais pertencentes à União, regulando e fiscalizando o setor.

Em 28 de novembro de 2018 foi publicado no Diário Oficial da União o Decreto $\mathrm{n}^{\circ}$ 9.587, aprovando a estrutura regimental, o quadro demonstrativo dos cargos em comissão da Agência Nacional de Mineração e exonerando os ocupantes dos cargos em comissão e das funções de confiança previstos no artigo vinte e dois da Lei $n^{\circ} 13.575$.

A nova estrutura organizacional compreende uma diretoria colegiada, gabinete do diretorgeral, secretaria-geral, procuradoria federal especializada, ouvidoria, auditoria interna, corregedoria, superintendências e unidades administrativas regionais.

Foram alterados pela Lei $\mathrm{n}^{\mathrm{o}}$ 13.575/2017 os aspectos relacionados à taxa para o exercício da atribuição de poder de polícia da Agência, enquadramento dos salários dos servidores e ainda fiscalizações presenciais nos empreendimentos minerários a fim de objetivar o aproveitamento racional das jazidas e da garantia da segurança técnica.

\subsubsection{Maior desastre ambiental do Brasil e o Novo Código de Mineração}

Ainda sobre a atividade mineradora no Brasil e o Decreto ${ }^{\circ}$ 9.406/2018 (novo Código de Mineração), é importante falar sobre o rompimento de barragem ocorrido em Mariana- MG em 2015, quando a barragem de Fundão da mineradora Samarco se rompeu, causando uma grande quantidade de lama, devastando o distrito de Bento Rodrigues no munícipio de Mariana- MG, tornando-se o maior desastre ambiental do Brasil. A lama ocasionou, além de perdas humanas e materiais, um grave impacto ambiental. Inclusive, foi fator primordial no que concerne as medidas preventivas previstas no novo código de mineração ${ }^{53}$, onde antes o foco era apenas sobre questões econômicas.

A barragem do Fundão da mineradora Samarco abrigava cerca de 56,6 milhões de $\mathrm{m}^{3}$ de rejeito de minério e água. Desse total, 43,7 milhões de $\mathrm{m}^{3}$ vazaram. O Serviço Autônomo de Água e Esgoto (SAAE) do Baixo Guandu -ES, solicitou exames, onde as amostras coletadas no rio Doce apontaram concentrações estratosféricas de metais pesados como o ferro que apontou um índice de $1.366 .666 \%$ ficando um milhão e trezentos mil acima do recomendado, o alumínio

${ }^{53}$ BRASIL. Decreto- Lei no 227, de 28 de fevereiro de 1967. Dá nova redação ao Decreto-Lei no 1.985 , de 29 de janeiro de 1940 (código de minas). Disponível em: www.planalto.gov.br/ccivil/decreto-lei/del0227.htm.Acesso em: 31 de maio de 2019. 
estava com concentração acima de $645.000 \%$ permitido e o manganês, metal tóxico, possuía níveis acima de $118.000 \%$ tolerado impossibilitando o tratamento.

Com o rompimento da barragem de rejeito, formou-se uma lama seca, pobre em matéria orgânica, tornando o solo infértil, no qual nenhuma espécie vegetal conseguiria desenvolver-se. A lama atingiu também os rios da região, chegando ao Rio Doce, que desagua no Oceano Atlântico no Estado do Espírito Santo, ocasionando a morte das espécies que viviam naquele ambiente, tanto nos rios como em algumas espécies do ecossistema marinho. Após um mês desse desastre, foram retiradas onze toneladas de peixes mortos, sendo a sua maioria no Estado de Minas Gerais.

A lama também provocou o desvio de curso de água dos rios e o soterramento de nascentes. Assim se fizeram necessários mudanças no novo Código de Mineração de forma a prevenir tais desastres.

\subsection{Regimes de aproveitamento minerário e seus institutos}

Os regimes de exploração e aproveitamento mineral estão disciplinadas no Decreto $\mathrm{n}^{\circ}$ 9.406/2018 novo Código de Mineração.

Os regimes de aproveitamento de recursos minerais são o regime de autorização, regime de concessão, regime de licenciamento, regime de permissão de lavra garimpeira e regime de monopolização e estão previstos no artigo 13 do novo Código de Mineração.

\subsubsection{Regime de autorização}

O regime de autorização de pesquisa é o mais antigo e considerado o mais completo dos regimes de recursos minerais. Nascido com o Código de Mineração em 1967, é previsto para todas as substâncias minerais com ressalva para aquelas protegidas pelo regime de monopolização e os garimpáveis localizados em áreas de garimpagem. Busca a comprovação da existência de jazida, para, só após essa comprovação, permitir a lavra dessa jazida por meio da concessão de lavra.

Trata-se então de um regime exploratório, ou seja, não constitui um regime de aproveitamento independente, todavia integra o regime de concessão e autorização. Permite ao minerador uma análise e pesquisa que comprovem a presença de jazida na área além de comprovar o interesse nacional e a utilidade pública.

De acordo com a legislação minerária, a pesquisa dessa natureza compreende os seguintes trabalhos de campo e de laboratório: levantamentos geológicos pormenorizados da área a pesquisar em escala conveniente; estudos dos afloramentos e suas correlações; levantamentos geofísicos e geoquímicos; abertura de escavações visitáveis e execução de sondagens no corpo mineral; amostragens sistemáticas; análises físicas e químicas das amostras e dos testemunhos de sondagens; e ensaios de beneficiamento dos minérios ou das substâncias minerais úteis, para obtenção de concentrados de acordo com as especificações do mercado ou aproveitamento industrial $^{54}$.

O Alvará de Pesquisa é outorgado pelo Diretor Geral da ANM e em seguida publicado no Diário Oficial da União, tendo a data limite para realizar a pesquisa o prazo não inferior a 1

${ }^{54}$ Portal da outorga. Disponível em: www.anm.gov.br Acesso em: 26 de maio de 2019. 
ano e não superior a 03 anos. Com relação as áreas concedidas, estas não podem ultrapassar os 2. 000 hectares, com exceção da Amazônia legal, que a área máxima é de 10.000 hectares. O requerente não precisa ser proprietário do solo, todavia é necessária uma autorização para entrar na propriedade.

Pode requerer a autorização de pesquisa e lavra de recursos minerais brasileiros, pessoa natural, firma individual ou empresas legalmente habilitadas, sendo de responsabilidade técnica de profissional legalmente habilitado, engenheiro de minas ou geólogos, com o registro no conselho da classe. O requerimento é feito por meio de formulário de pré-requerimento eletrônico, que deverá ser entregue na superintendência em que se situa a área pretendida juntamente com a documentação comprobatória, tratando de pessoa física, documentos com indicação de nacionalidade, estado civil, profissão, domicílio e número de inscrição no CPF. Em caso de pessoa jurídica, documentos que indiquem a razão social, número do registro dos atos constitutivos no Órgão de Registro de Comércio, número de inscrição no Cadastro Geral de Contribuintes e endereço. Ainda se faz necessário juntar prova de recolhimento dos respectivos emolumentos, designação das substâncias a pesquisar, indicação da extensão da área objetivada, em hectares e o endereço da mesma, coordenadas por meio de sistema indicado pela ANM, planta contendo elementos de cartografia como ferrovias, rodovias, rios entre outros e o plano dos trabalhos de pesquisa, acompanhado de cronograma e orçamento.

Conforme o artigo 25 do novo Código de Mineração, ao concluir os trabalhos, o titular da autorização é obrigado a apresentar, no prazo de sua vigência, relatório final dos trabalhos realizados independentemente do resultado da pesquisa. Uma vez aprovado o relatório, o titular dispõe de 01 ano para requerer a concessão de lavra, prorrogável por igual período mediante solicitação do titular.

\subsubsection{Regime de concessão de lavra}

Com a demonstração da existência de jazidas na área autorizada e com o relatório dos trabalhos de pesquisa aprovado, o titular da autorização passa a adquirir o direito de requerer junto a ANM, no prazo de 01 ano, prorrogável por igual período, o título de concessão de lavra dessa jazida, ou seja, o direito real de aproveitamento de uma jazida.

O artigo 34 do novo Código de Mineração trata das obrigações do titular, nestes termos:

\footnotetext{
Art. 34. Além das condições gerais que constam do Decreto-Lei no 227, de 1967 Código de Mineração e deste Decreto, o titular da concessão fica obrigado, sob pena das sanções previstas em lei, a:

I - iniciar os trabalhos previstos no plano de aproveitamento econômico no prazo de seis meses, contado da data de publicação da concessão de lavra no Diário Oficial da União, exceto por motivo de força maior, a juízo da ANM;

II - lavrar a jazida de acordo com o plano de aproveitamento econômico aprovado pela ANM;

III - extrair somente as substâncias minerais indicadas na concessão de lavra;

IV - comunicar à ANM o descobrimento de qualquer outra substância mineral não incluída na concessão de lavra;
}

Uma característica da concessão de lavra é o fato de não possuir um prazo de duração preestabelecido, subentendendo-se que a concessão de lavra dura até a exaustação da jazida desde que o titular obedeça a todos os requisitos. 


\subsubsection{Do regime de licenciamento}

O regime de licenciamento permite que o titular extraía substâncias minerais com finalidade econômica. O artigo 39 do novo Código de Mineração aduz que o aproveitamento de recursos minerais sob esse regime obedece ao disposto na Lei $n^{\circ} 6.567 / 1978^{55}$.

Podem ser aproveitados pelo regime de licenciamento, ou de autorização e concessão, em uma área máxima de cinquenta hectares, areias, cascalhos e saibros para a utilização imediata na construção civil desde que não sejam submetidos a processos industriais, rochas e outras substancias minerais desde que para a produção de paralelepípedos, guias, sarjetas, moirões e afins, argilas usadas na fabricação de cerâmica vermelha e rochas britadas para uso imediato na construção civil e os calcários empregados como corretivo de solo na agricultura ${ }^{56}$.

É facultado ao proprietário do solo exclusivamente ou àquele que dele obtiver expressa autorização, sendo necessária uma licença prévia expedida pela autoridade administrativa do município o qual encontra-se a jazida e, do registro junto a Agência Nacional de Mineração e tendo um dos requisitos a nacionalidade brasileira do titular.

Para solicitar o requerimento de licenciamento na Agência Nacional de Mineração, primeiramente, é necessário apresentar o pré-requerimento eletrônico, disponível no site da Agência Nacional de Mineração.

Há ainda outros requisitos para o requerimento de licenciamento, como documentos que comprovem a nacionalidade brasileiro, caso seja o requerente pessoa física, ou documentos que comprovem o número de inscrição no CNPJ, do Ministério da Fazenda e o número de registro no Órgão de Registro do Comércio da sede e documentos que descrevam a área pretendida por meio de coordenadas geodésicas, prova de recolhimento de emolumentos, licenças municipais, instrumento de autorização do proprietário do solo ou declaração do requerente ser o proprietário, plano de aproveitamento econômico, anotação de responsabilidade técnica e procuração com firma reconhecida, pública ou particular, caso o requerimento não for assinado pelo requerente. A natureza jurídica desse regime é de concessão de exploração, uma vez que o objetivo é possibilitar a exploração de bem público, o qual atribui obrigações à Administração e também ao particular, com normas preexistentes.

\subsubsection{Regime de permissão de lavra garimpeira}

O parágrafo primeiro do artigo primeiro da lei $n^{\circ} 7.805 / 198$ expressa que o regime de lavra garimpeira é o aproveitamento imediato de jazimento mineral que, por sua natureza, dimensão, localização e utilização econômica, possa ser lavrado independentemente de prévios trabalhos de pesquisa, segundo critérios fixados pela Agência Nacional de Mineração.

Consideram-se substâncias minerais garimpáveis o ouro, o diamante, quartzo, berilo, feldspato, mica, sheelita, dentre outros, ou seja, aquelas que são executadas no interior de áreas

\footnotetext{
55 Brasil. Lei $\mathrm{n}^{\circ}$ 6.567, de 24 de setembro de 1978. Dispõe sobre regime especial para exploração e o aproveitamento das substâncias minerais que específica e dá outras providências. Disponível em: www.planalto.gov.br/ccivil_03/LEIS/16567.htm. Acesso em: 27 de maio de 2019.

${ }^{56}$ BRASIL. Lei ${ }^{\circ}$ 6.567, de 24 de setembro de 1978. Dispõe sobre regime especial para exploração e o aproveitamento das substâncias minerais que específica e dá outras providências. Disponível em: www.planalto.gov.br/ccivil_03/LEIS/16567.htm. Acesso em: 27 de maio de 2019.
} 
estabelecidas para a garimpagem, exercida por brasileiro, cooperativa de garimpeiros, autorizada a funcionar como empresa de mineração, sob o regime de permissão de lavra garimpeira.

Para a exploração no regime de permissão de lavra garimpeira é necessário a prévia obtenção de licenciamento ambiental expedido por órgão estadual competente ou ainda pelo Instituto Brasileiro do Meio Ambiente e dos Recursos Naturais Renováveis - IBAMA e, posteriormente, uma portaria de permissão do Diretor Geral da Agência Nacional de Mineração.

O título tem vencimento em 05 anos, podendo ser renovado pela Agência Nacional de Mineração sucessivamente. A área a qual se pede permissão não pode exceder 50 hectares, salvo nos casos os quais são outorgadas a cooperativa de garimpeiros.

Para a concessão de permissão de lavra garimpeira a Agência Nacional de Mineração adotou uma série de requisitos, sendo o primeiro a realização de um formulário eletrônico. Ainda se faz necessário, além da nacionalidade brasileira para pessoa física e de comprovante de registro dos atos constitutivos no órgão de registro de comércio na sede, que seja uma cooperativa de garimpeiros ou firma individual, as cópias dos estatutos ou contrato social ou ainda a declaração de firma individual, prova de recolhimento de emolumentos, coordenadas geodésicas da área pretendida entre outros.

Conclui-se que os regimes de aproveitamento têm por objetivo a obtenção de um título de habilitação, os quais conceda o direito de aproveitar os recursos minerais presentes no solo e subsolo de forma legal, independentemente das substâncias as quais pretende-se extrair ou a sua quantidade. É pertencente a todos os Brasileiros e de domínio da União Federal conforme previsto na $\mathrm{CF} / 88$.

\section{CONSIDERAÇÕES FINAIS}

A história do Direito Ambiental brasileiro inicia-se ainda nos tempos do Brasil Colônia e ganhou destaque nas últimas décadas. A Conferência de Estocolmo, em Estocolmo, Suécia, 1972, deu início a uma sequência de atos visando o desenvolvimento sustentável, sendo o principal meio para a discussão do meio ambiente internacionalmente.

A amplitude dessa temática possibilitou uma visão dos diversos sentidos que o Direito descobriu para efetivar a proteção ao meio ambiente.

Alguns princípios possuem superior aplicabilidade de execução atualmente, enquanto outros ainda buscam esse objetivo.

Assim, os princípios do Direito Ambiental são de suma importância para a efetiva aplicação dessa legislação.

Conclui-se por meio desse trabalho que nos últimos anos o setor do Direito Minerário sofreu grandes modificações com a criação da Agência Nacional de Mineração (Lei 13. 
575/2017 ${ }^{57}$ ), do novo código de mineração (Decreto $n^{\circ}$ 9.406/2018 $8^{58}$ ) e da Lei que dispõe sobre a Compensação Financeira por Exploração de Recursos Naturais - CFEM (Lei no ${ }^{\text {13 }} .540 / 2017^{59}$ ).

Muito embora a legislação ambiental esteja mais rigorosa, podemos observar que ainda assim ocorrem desastres ambientais, como no caso do rompimento da barragem em Mariana Minas Gerais.

\section{REFERÊNCIAS}

AMADO, Frederico Augusto Di Trindade. Direito ambiental esquematizado. 2. ed, São Paulo: método, 2011.

ANTUNES, Paulo de Bessa. Direito Ambiental, 14. ed., São Paulo: Atlas, 2012.

BELTRÃO, Antônio Figueiredo Guerra. Curso de Direito Ambiental. 2, ed. red., atual. ampl. São Paulo: Método. 2014.

BRASIL. Constituição da República Federativa do Brasil. Brasília: Senado, 1988.

BRASIL. Lei n. 8.078, de 11 de setembro de 1990. Dispõe sobre a proteção do consumidor e dá outras providências. Disponível em: http://www.planalto.gov.br/ccivil_03/leis/18078.htm. Acesso em: 05 dez. 2018.

BRASIL. Supremo Tribunal Federal. Notícias STF. Na China, ministro Lewandowski destaca papel do judiciário na proteção ambiental. Disponível em: www.stf.jus.br/portal/cms/verNoticiaDetalhe.asp?idConteudo Acesso em 13 maio 2019.

BRASIL. Supremo Tribunal Federal. Acórdão proferido em Ação Direta de Inconstitucionalidade $\mathbf{N}^{\circ}$ 4.029/AM. Ação Direta Parcialmente Procedente. Órgão Julgador: Tribunal Pleno. Relator: Ministro Luiz Fux. Julgado em 08 mar. 2012. Disponível em: http://portal.stf.jus.br/. Acesso em: 13 maio 2019.

BRASIL. STF. ADI: 3378, DF, Relator: CARLOS BRITTO. Data de julgamento; 09 de abr de 2008. Tribunal do Pleno. Data de publicação: DJe-112 DIVULG 19 de jun de 2008. PUBLIC 20 de jun de 2008. EMENT VOL-02324-02 PP- 00242.

BRASIL. Lei n 6.938, de 31 de agosto de 1981. Dispõe sobre a política nacional do meio ambiente, seus fins e mecanismos de formulação e aplicação, e dá outras providências. Disponível em:www.planalto.gov.br/ccivil_03/leis/16938.htm. Acesso:16 maio 2019.

BRASIL. Lei no 9.433, de 8 de janeiro de 1997. Institui a Política Nacional de Recursos Hídricos, cria o Sistema Nacional de Gerenciamento de Recursos Hídricos, regulamenta o inciso XIX

${ }^{57}$ BRASIL. Lei $n^{\circ}$ 13.575, de 26 de dezembro de 2017. Cria a Agência Nacional de Mineração (ANM), extingue o Departamento Nacional de Produção Mineral (DNPM); altera as Leis nº 11.046, de 27 de dezembro de 2004, e 10.826, de 22 de dezembro de 2003; e revoga a Lei $\mathrm{n}^{\circ}$ 8.876, de 2 de maio de 1994, e dispositivos do Decreto-Lei $\mathrm{n}^{\circ} 227$, de 28 de fevereiro de 1967 (Código de Mineração). Disponível em: http://www.planalto.gov.br/ccivil_03/_Ato20152018/2017/Lei/L13575.htm. Acesso em: 31 maio 2019.

58 BRASIL. Decreto $n^{\circ}$ 9.406, de 12 de junho de 2018. Regulamenta o Decreto-Lei $\mathrm{n}^{\circ}$ 227, de 28 de fevereiro de 1967, a lei $\mathrm{n}^{\circ} 6.567$, de 24 de setembro de 1978, a Lei $\mathrm{n}^{\circ} 7.805$, de 18 de julho de 1989, e a Lei $\mathrm{n}^{\circ} 13.575$, de 26 de dezembro de 2017. Disponível em: www.planalto.gov.br/ccivil 03/_Ato2015-2018/2018/Decreto/D9406.htm. Acesso em: 31 maio 2019.

59 BRASIL. Lei 13.540, de 18 de dezembro de 2017. Altera as Leis n ${ }^{\circ} 7.990$, de 28 de dezembro de 1989, e 8.001, de 13 de março de 1990, para dispor sobre a Compensação Financeira pela Exploração de Recursos Minerais (CFEM). Disponível em: http://www.planalto.gov.br/ccivil_03/_Ato2015-2018/2017/Lei/L13540.htm. Acesso em: 31 maio 2019. 
do art. 21 da Constituição Federal, e altera o art. $1^{\circ}$ da Lei no 8.001, de 13 de março de 1990, que modificou a Lei ${ }^{\circ}$ 7.990, de 28 de dezembro de 1989. Disponível em: www.planalto.gov.br/ ccivil_03/leis/19433.htm. Acesso em: 31 maio 2019.

BRASIL. Lei Complementar $n^{0}$ 140, de 8 de dezembro de 2011. Fixa normas, nos termos dos incisos III, VI e VII do caput e do parágrafo único do artigo 23 da Constituição Federal, para a cooperação entre a União, os Estados, o Distrito Federal e os Municípios nas ações administrativas decorrentes do exercício da competência comum relativas à proteção das paisagens naturais notáveis, à proteção do meio ambiente, ao combate à poluição em qualquer de suas formas e à preservação das florestas, da fauna e da flora; e altera a Lei no 6.938, de 31 de agosto de 1981. Disponível em: www.planalto.gov.br/ccivil_03/leis/lcp/lcp140.htm.

BRASIL. STF. ACO 876 MC-AgR / BA - BAHIA. AG.REG.NA MEDIDA CAUTELAR NA AÇÃO CÍVEL ORIGINÁRIA Relator(a): Min. MENEZES DIREITO. Julgamento: 19/12/2007. Órgão Julgador: Tribunal Pleno Publicação DJe-142 DIVULG 31-07-2008 PUBLIC 01-08-2008 EMENT VOL-02326- 01 PP-00044 RTJ VOL-00205-02 PP-00537. Disponível em: https://stf.jusbrasil.com.br/jurisprudencia/14723924/agregna-medida-cautelar-na-acao-civeloriginaria-aco-876-ba. Acesso em: 31 maio 2019.

BRASIL, Lei n⿳ 11.105, de 24 de março de 2005. Regulamenta os incisos II, IV e V do $\S 1^{\circ}$ do art. 225 da Constituição Federal, estabelece normas de segurança e mecanismos de fiscalização de atividades que envolvam organismos geneticamente modificados - OGM e seus derivados, cria o Conselho Nacional de Biossegurança- CNBS, reestrutura a Comissão Técnica Nacional de Biossegurança - CTNBio, dispõe sobre a Política Nacional de Biossegurança - PNB, revoga a Lei $n^{\circ} 8.974$, de 5 de janeiro de 1995, e a Medida Provisória $n^{\circ} 2.191-9$, de 23 de agosto de 2001 , e os arts. $5^{\circ}, 6^{\circ}, 7^{\circ}, 8^{\circ}, 9^{\circ}, 10$ e 16 da Lei n ${ }^{\circ} 10.814$, de 15 de dezembro de 2003 , e dá outras providências. Disponível em: www.planalto.gov.br/ccivil_03/_ato2004-2006/2005/lei/111105. htm. Acesso em: 31 maio 2019.

BRASIL. Lei n 6.938, de 31 de agosto de 1981. Dispõe sobre a política nacional do meio ambiente, seus fins e mecanismos de formulação e aplicação, e dá outras providências. Disponível: www.planalto.gov.br/ccivil_03/leis/16938.htm. Acesso: 16 maio 2019.

BRASIL. Lei n 9.985 de 18 de julho de 2000. Regulamenta o artigo 225 , $§ 1^{\circ}$ Art. $2^{2}$ incisos I, II, III e IV da Constituição Federal, institui o sistema nacional de unidades de conservação da natureza e dá outras providências. Art. $2^{\circ}$ Para os fins previstos nesta Lei, entende-se por: IV Recurso ambiental: a atmosfera, as águas interiores, superficiais e subterrâneas, os estuários, o mar territorial, o solo, o subsolo, os elementos da biosfera, a fauna e a flora; Disponível em: www.planalto.gov.br/ccivil_03/leis/19985.htm Acesso 16 maio 2019.

BRASIL. Lei $\mathbf{n}^{\mathbf{0}} 3.071$ de $1^{\mathbf{0}}$ de janeiro de 1916. Disponível em: www.planalto.gov.br/ccivil 03/leis/13071.htm. Acesso em: 20 de maio de 2019.

BRASIL. STF. Ag. Reg. Em RE no 140.254-7. Rel. Min. Celso de Mello, DJ de 6-6-1997. Informativo STF n ${ }^{\circ}$ 74. Disponível em: www.stf.jus.br/portal/constituicao/artigoBd.as?item=1699. Acesso:20 maio 2019.

BRASIL. Decreto- Lei $\mathbf{n}^{0}$ 227, de 28 de fevereiro de 1967. Dá nova redação ao Decreto-Lei ${ }^{\circ}$ 1.985, de 29 de janeiro de 1940 (código de minas). Disponível em: $\underline{w w w . p l a n a l t o . g o v . b r / c c i v i l / ~}$ decreto-lei/del0227.htm. Acesso em: 25 de maio de 2019.

BRASIL. Decreto no 9.406, de 12 de junho de 2018. Regulamenta o Decreto-Lei $\mathrm{n}^{\mathbf{0}} 227$, de 28 de fevereiro de 1967, a lei $\mathrm{n}^{\mathrm{o}}$ 6.567, de 24 de setembro de 1978, a Lei $\mathrm{n}^{\mathrm{o}} 7.805$, de 18 de julho 
de 1989, e a Lei $\mathrm{n}^{\text {o }}$ 13. 575, de 26 de dezembro de 2017. Disponível em: www.planalto.gov.br/ccivil_03/Ato2015-2018/2018/Decreto/D9406.htm Acesso:27 maio 2019

BRASIL, Decreto- Lei no 227 , de 28 de fevereiro de 1967. Dá nova redação ao Decreto-Lei ${ }^{\circ}$ 1.985, de 29 de janeiro de 1940 (código de minas). Disponível em: www.planalto.gov.br/ccivil/ decreto-lei/del0227.htm. Acesso em: 31 maio 2019.

BRASIL. Lei $\mathbf{n}^{\mathbf{0}} \mathbf{6 . 5 6 7}$, de 24 de setembro de 1978. Dispõe sobre regime especial para exploração e o aproveitamento das substâncias minerais que específica e dá outras providências. Disponível em: www.planalto.gov.br/ccivil_03/LEIS/16567.htm. Acesso em: 27 maio 2019.

BRASIL. Lei $\mathbf{n}^{\mathbf{0}}$ 13.575, de 26 de dezembro de 2017. Cria a Agência Nacional de Mineração (ANM), extingue o Departamento Nacional de Produção Mineral (DNPM); altera as Leis $\mathrm{n}^{\circ}$ 11.046, de 27 de dezembro de 2004, e 10.826, de 22 de dezembro de 2003; e revoga a Lei $\mathrm{n}^{\circ}$ 8.876, de 2 de maio de 1994, e dispositivos do Decreto-Lei no 227, de 28 de fevereiro de 1967 (Código de Mineração). Disponível em: http://www.planalto.gov.br/ccivil 03/_Ato2015-2018/ 2017/Lei/L13575.htm. Acesso em: 31 maio 2019.

BRASIL. Decreto no 9.406, de 12 de junho de 2018. Regulamenta o Decreto-Lei $\mathrm{n}^{\circ} 227$, de 28 de fevereiro de 1967, a lei $\mathrm{n}^{\circ}$ 6.567, de 24 de setembro de 1978, a Lei $\mathrm{n}^{\mathrm{o}} 7.805$, de 18 de julho de 1989, e a Lei $\mathrm{n}^{\circ}$ 13. 575, de 26 de dezembro de 2017. Disponível em: www.planalto.gov.br/ ccivil_03/Ato2015-2018/2018/Decreto/D9406.htm. Acesso em: 31 maio 2019.

BRASIL. Lei 13.540, de 18 de dezembro de 2017. Altera as Leis $n^{\circ} 7.990$, de 28 de dezembro de 1989, e 8.001, de 13 de março de 1990, para dispor sobre a Compensação Financeira pela Exploração de Recursos Minerais (CFEM). Disponível em: http://www.planalto.gov.br/ccivil 03/ Ato2015-2018/2017/Lei/L13540.htm. Acesso em: 31 maio 2019.

CONAMA, Resolução no 237, de 19 de dezembro de 1997. Disponível em: http://extwprlegs1. fao.org/docs/pdf/bra25095.pdf. Acesso em: 31 maio 2019.

FEIGELSON, Bruno. Curso de Direito Minerário. $2^{\text {a }}$ Ed. São Paulo: Saraiva, 2014.

FERNANDES, Paula. Seio de Minas. Disponível em: https://www.letras.mus.br/paula-fernandes/1603654/ Acesso em: 31 maio 2019.

FIORILLO, Celso Antônio Pacheco. Curso de direito ambiental brasileiro. 8, ed. rev., atual, e ampl. São Paulo: Saraiva. 2007.

FÓRUM DAS NAÇÕES UNIDAS SOBRE O MEIO AMBIENTE DE 1972. Declaração de Estocolmo. Disponível em: http://www.direitoshumanos.usp.br/index.php/meio-ambiente/declaracao-de-estocolmo-sobre-o-ambiente-humano.html. Acesso 13 maio 2019.

FÜHRER, Maximilianus C. A.; MILARÉ, Édis. Manual de direito público e privado. 17. ed. São Paulo: RT, 2009.

GABBO, Marco Aurélio. GABBO, Rogério. Meio Ambiente. Projeto educando cantando. Disponível em: www.letras.mus.br/projeto educando cantando/1110508. Acesso em: 31 maio 2019.

HERRMANN, H. A mineração sob a óptica legal. In: LINS, F. A. F.; LOUREIRO,F. E. V. L; ALBUQUERQUE, G. A. S. C. de. Brasil 500 anos - a construção do Brasil e da América Latina pela mineração: histórico, atualidades e perspectivas. Rio de Janeiro: CETEM/MCT, 2000 .

MACHADO, Paulo Affonso Leme. Direito ambiental brasileiro, 17. ed., rev. atual. e ampl. São Paulo: Malheiros. 2011. 
MILARÉ, Edis. Direito do Meio Ambiente. $7^{\text {a }}$ ed., revista, atual. e ampliada. São Paulo: Revista dos Tribunais, 2010.

NORMA PRINCÍPIO No 16, Conferência das Nações Unidas sobre o Meio Ambiente e o Desenvolvimento, 1992. Disponível em: www.meioambiente.pr.gov.br/Declaracao_Rio_Meio Ambiente_Desenvolvimento. Acesso em: 14 maio 2019.

POVEDA, Eliane Pereira Rodrigues. A eficácia legal na desativação de empreendimentos minerários. São Paulo: Signus. 2007.

RODRIGUES, Marcelo Abelha. Instituições de direito ambiental. 5, ed. rev., atual. ampl. São Paulo: Max Limonad, 2002. p. 138.

SILVA, Romeu Faria Thomé da. Manual de direito ambiental. 7. ed., rev. atual. e ampl. Salvador: Jus podivm. 2017.

SAPIENS. Sistema AGU de inteligência jurídica. gerenciador eletrônico de documentos (GED), híbrido, que possui recursos de apoio para a produção de conteúdo e controle de fluxo de trabalho, focado na integração com os sistemas informatizados do Poder Judiciário e do Poder Executivo. Disponível em: www.sapiens.agu.gov.br. Acesso em: 15 maio 2019.

SERRA, Silvia Helena. Direitos minerários: formação, condicionantes e extinção. São Paulo: Signus Editora, 2000.

Submetido em: 4 jun. 2019.

Aceito em: 17 maio 2021. 